\title{
Correlate of Workforce Diversity and Organisational Performance of Multinational Food Producing Industry in Nigeria
}

http://doi.org/10.21272/bel.4(1).126-137.2020

Kowo Solomon Akpoviroro, ORCID: https://orcid.org/0000-0002-0504-2248

$\mathrm{PhD}$, Course Facilitator, Department of Business and Entrepreneurship, Kwara State University, Malete, Nigeria

Kadiri Bolarinwa Ismaila, ORCID: https://orcid.org/0000-0003-0564-4833

$\mathrm{PhD}$, Head of the Department of Industrial Relations and Personnel Management, University of Ilorin, Kwara State, Nigeria

Zekeri Abu, ORCID: https://orcid.org/0000-0002-0567-4432

$\mathrm{PhD}$, Post Graduate Coordinator, Department of Business and Entrepreneurship, Kwara State University, Malete, Nigeria

\begin{abstract}
The paper summarizes the arguments and counterarguments within the scientific discussion on the issue cultural and age diversity of workforce and the level of workers' productivity in the multinational companies. Three hundred and seventy-five employees from five multinational food companies in Southwest Nigeria form the object of the research. Methodological research tools contain questionnaires; the regression analysis methods was used when testing hypotheses on the existence of a correlation between cultural diversity and team performance; cross-tabulation analysis method; inter-position correlation test, and ANOVA method for generalizing and interpreting the results. The results of the study regarding the relationship between a company's cultural diversity and its market share showed that cultural diversity does not affect the performance of the organization's employees, while work experience has a non-linear impact on the company's productivity. The results of findings conclude that there is a link between workforce diversity and the organizational effectiveness of the company, as well as the positive relationship between the cultural diversity of employees and their work experience. The findings of the study are agreed with the work of other scientists on the subject and complement their results. According to the results of the analysis, it was concluded that it is necessary to increase the level of awareness of the staff about the cultural diversity that exists in the organization. The reason is that it is necessary to increase the employees' morale and their work efficiency, which will increase the level of customer satisfaction with the work of the company. The study recommends that; multinational food producing industries should not only ensure employee diversity in their businesses but they should also make sure that diversity is used to improve organizational performance. Future research in this area should focus on consideration of all stakeholders' opinions in the formulation of multinational company's personnel policies.
\end{abstract}

Keywords: Employees Diversity, Organizational Performance, Cultural Diversity, Work Experience Diversity, MNCs.

JEL Classifications: M14, J21, L25.
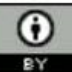

This work is licensed under a Creative Commons Attribution 4.0 International License

Cite as: Kowo, S.A., Kadiri B.I., Zekeri, A. (2020). Correlate of Workforce Diversity and Organisational Performance of Multinational Food Producing Industry in Nigeria. Business Ethics and Leadership, 4(1), 126-137. http://doi.org/10.21272/bel.4(1).126-137.2020.

(C) The Authors, 2020. This article is published with open access at Sumy State University.

\section{Introduction}

Diversity discussion in Nigeria has traditionally been dominated by cultural and religious issues. Nigeria places unusually high focus for the national diversity issues based on cultural and religious issues and has one of the five most diverse populations with poor workplace inclusion, a weak legal framework, government and social exclusivity in the world. Organizations embracing diversity in their workforce are working towards creating a 
culture where differences can thrive, rather than working simply for representatives and assimilation (Akinusi, Sonubi \& Oyewunmi; Danladi, 2013; Amstrong, 2012). Most attention on diversity management focused on the organizational decision-maker who is prejudiced against certain groups and who allows these prejudices to influence how he or she treats employees. Moreover, they become embodied in organizational policies and practices that systematically disadvantage some employees. According to Ojo (2012) people began to realize that visible, legally recognized, demographic differences such as race and gender were types of differences that affected work relationships among employees. Furthermore, most studies show that training programs on workforce diversity management, that presumed to enhance decision making, problem-solving, and creativity at work; rarely leads to the desired long-term changes in attitudes and behaviour. The principal objective of understanding the impacts of workforce diversity on organizational outcomes, such as organizational performance, employee satisfaction, and voluntary employee turnover, is the key to organizational sustainability (Ozbilgin \& Tatli, 2016; Kochan et al., 2012). Torrington \& Taylor (2015) posit that Workforce diversity is proclaimed as an opportunity for organizations to become more creative, to reach previously untapped markets, and as such this research would assist Nigerian multinationals to achieve and maintain a competitive advantage. The optimum outcome of this study is to benefit the Multinational Food industry in Nigeria by getting along with the top management and workers from different backgrounds that would find the information in this research study useful in accessing the value of workforce diversity in their organization. Implementation of workforce diversity promotes political stability by unlocking the potential for excellence among all the workers by providing those tools, resources and opportunities to succeed (Ricardo, 2016; Okpanachi, 2012; Ndubisi; 2006; Greenberg, 2014). On the other hand, it allowed for a mediator to communicate between the two cultures effectively and efficiently. As a conclusion, decades of research on the effects of diversity within teams and small groups indicate that diversity can have negative effects, as well as positives ones (Linnenluecke, 2017; Richard, 2014). Moreover, they elaborated that there is a clear lack of evidence linking workforce diversity to organizational. Therefore, this study focuses on the relationship between gender, age, culture, and work experience and organizational performance in multinational organizations.

\section{Statement of the Problem}

Hassan (2013) pointed out that diversity is not just a racially contentious issue but one of culture as an inappropriate understanding of the culture of organizations in any country would affect the way the workforce operates. Cultural diversity focuses on the conduct and behaviours of individuals who come from different ethnic backgrounds, of different languages as well as varying religious beliefs (Ogunyinka, 2013; Oliver, 1999; Konrad, 2013; Gelner \& Veen, 2013). Most firms pay less attention to cultural differences as it affects employee performance at work about productivity because it's not mostly considered as an inhibitor to organizational performance. There have been a significant number of studies that have explored the effect of diversity at individual and group level; there are little theoretical guidance and a scarcity of empirical findings concerning the potentially beneficial impact of firm-level cultural diversity on organizational performance. Managing employee work experience diversity in the workplace should be the concern of every organization as companies need to be able to manage and utilize its diverse workplace experience effectively. Childs (2016) pointed out that work experience diversity management practices enhance productivity, effectiveness, and sustained competitiveness. The focus on differences in individual characteristics leading to inequality has posed the challenge of achieving unity in diversity and harnessing that diversity to improve employee performance. Failure to manage work experience diversity in terms of the level of education, profession, promotions, pay, training, turnover, mutual acceptance, job satisfaction and other forms of inequality in the workforce has been of contention in Multinational companies.

\section{Research Hypotheses}

\section{Hypotheses One}

$\mathrm{Ho}_{1}$ : Cultural diversity does not significantly affect the market share of multinationals Food Industry.

Hypotheses Two

$\mathrm{Ho}_{2}$ : Work experience does not significantly affect employee turnover of multinationals Food Industry.

\section{Literature Review}

\section{Concept of Diversity}

The trends of diversity started in the mid-1980s. It was proclaimed as an opportunity for a firm to maintain a competitive advantage (Gileth \& Hom, 2001; Long, Perumal \& Ajagbe, 2012). Decades of researchers define workforce diversity as a significant difference that distinguishes one individual from another (e.g., traits, skills 
and abilities), internal (e.g., gender, race, ethnicity, I.Q., sexual orientation), external (e.g., culture, nationality, religion, marital or parental status), and organizational (e.g., position, department, union/non-union) (Friday \& Friday, 2013; Erasmus, 2016; Ditomosa, 2015). Diversity is being regarded by scholars as understanding and celebrating differences among people. Multinational Firms focus so much on human capital development as a vital tool in managing their businesses, thus, diversity is a powerful factor that influences terminology worldwide (Weiliang et al., 2011; Duncan, 2013; CIPD, 2014). Some schools of thought had shown that people of similar backgrounds are attracted to themselves, they elaborate that people of similar religious backgrounds, ages, cultures, educational backgrounds prefer working with themselves (Erasmus, 2016). People began to understand that demographic differences such as race and gender were types of differences that affected work relationships among employees (Childs, 2016; Gelner \& Veen, 2013).

\section{Work Experience Diversity}

Adler (2014) noted that work experience was a better predictor of performance than age. A breakdown of jobs into five occupational groupings revealed a moderating effect for occupational type. Findings also showed that age and experience exhibit nonlinear relationships with performance. Experienced workers generally are viewed as dependable, loyal, and dedicated. They are also viewed as having a strong work ethic, solid performance record, due to possessing years of working related experience (Gupta, 2013; Porter, 1987; Maxwell, Blair \& McDougall, 2015). Work experience can also have a positive effect on one's value system, problemsolving capabilities, emotional intelligence, leading to improved individual productivity and overall organizational performance (Al-lamki, 2014; Dandi \& Ngugen, 2010; Allen, Bryant \& Vardamen, 2010). Two studies have shown that the length of work experience is positively related to work performance. Such experience involves the development of well-practiced work skills (Sunjo \& Rainy, 2014; Taylor, 2002; Zheng, Hyland \& Soosay, 2013). Otike, Messah \& Nwaleka (2010) have also argued that experienced workers can make faster work-related decisions, resolve problems quickly, which leads to more satisfied customers and increased market share. Thomas \& Eli (2014) have further argued that as employees continue to serve in their organizations, they are likely to gain more expertise due to their exposure relating to the different work environments. They can handle work challenges with more confidence and make faster decisions relating to customer complaints.

\section{Cultural Diversity}

Differences in cultural characteristics can predict team scores which can further be interpreted as an advantage of having ethnically different views for a team, resulting in increased problem solving and team performance. Many private firms have also manifested this kind of diversity, although a good number- especially the multinationals and those that have adopted professionalism as a value hire purely on merit (Meyer \& Sternthal, 1991; Pan \& Zinkam, 2006). While there have been a significant number of studies that have explored the effect of diversity at individual and group level, there are little theoretical guidance and a scarcity of empirical findings concerning the potentially beneficial impact of firm-level cultural diversity on organizational outcomes (Price, 1977; Cox, 2001). Researchers have observed that diversity in a cultural context can influence organizational synergies, innovativeness, and effectiveness in the implementation of technological programmes (Ajala \& Alonge, 2013; Robertson \& Park, 2007). Cultural diversity can further influence interpersonal dynamics within an organization. Interpersonal barriers rooted in cultural differences may impede the flow of information on a corporate-wide basis. Cultural norms and practices may further influence how human resource programmes are implemented (Singh \& Ramadhar, 2000). Okpanachi (2012) posit that cultural diversity is often perceived as a societal fact as in a country "it consists of citizens/inhabitants with different cultural backgrounds. Taijef (1986) emphasizes the importance of a firm's ability to deal and absorb the benefits from cultural diversity towards the wealth of the organization which is a key requirement for survival not just at the domestic level but even in the international settings. Atta and Asamoah (2011) posit that differences in people's values, attitude and behaviour that are grounded from diverse cultures influence how managerial events are viewed in an organization. Afolabi and Aina (2011) see culture as the software of mind that separate member of different groups from each other. From this definition, we can see cultural diversity as the presence of different cultures within a social system, which differs in values, norms and behaviour. Therefore people of different cultures can be different from each other in many ways (Borman \& Penner, 2001).

\section{Challenges of Workforce Diversity}

Greenberg (2014) opined that the major obstacles are communication, resistance to change, and implementation of diversity in the workplace. Ozbilgin and Tatli (2016) pointed out that meeting diversity challenges requires a strategic human resource plan that entails many different strategies to enhance diversity and promote effectiveness and efficiency in the organization. It also compels Human resource managers to 
solicit a trainable population, check required skills and competencies against the job, market jobs sufficiently ahead of needs, and extend the workforce boundaries to include the nationals of other countries (Afolabi \& Aina, 2014). Taylor (2002) emphasized that HRMs are faced with the challenge of convincing their senior management that diversity in organizations is beneficial to the organization. Following social identity theory, it is possible to explain the lack of positive association between gender and ethnic diversity and performance reported in the major investigation by Kochan et al. (2012). For example, it has been argued that members of diverse groups (particularly minority groups or out-groups) frequently provoke distrust and competition (from the dominant groups or in groups) and that such groups tend to show less affiliation and commitment to each other, all of which may have negative consequences for performance (Opanachi, 2012).

\section{Workforce Diversity Management}

Sungjoo and Rainey (2014) posit that Employees may have low self-esteem or isolated due to their race and national origin. Hence, top management must pay high attention to employee perceptions regarding cultural diversity either through the organization structure or formal and informal communications. It is important for management to recognize employee perceptions that foreign workers are supported and integrated into informal networks. Once they recognize management support, they will feel integrated into their informal network and work in a positive working environment (Ogunyinka, 2013; Daladi 2013). Moreover, people in respective of gender should be treated equally as individuals and group differences should be ignored when making strategic decisions and plans such as hiring, recruiting and promotions (Childs, 2016). The organization that accepts cultural diversity management as a tool will benefit more effectively from employees retention, increase market share, effective operational costs, high sales patronage, increase productivity, better morale, less absenteeism and improved customer service (Ozbilgin \& Tatli, 2016). The merit of diversity to firm's performance depends on the organization's legal and political environment, geographical location, global orientation and firms strategy (Ogunyinka, 2013).

\section{Theoretical Framework}

\section{Blau's Theory of Heterogeneity}

Blau (1977) argued in his theory of heterogeneity that firms with different levels of cultural background experience dissimilar outcomes. According to (Blau, 1977), the similarities will promote the social association. However, the inflow of diverse workers does not necessarily mean that all organizational groups will assemble diversely. Any successful management of workforce diversity must involve a change in organizational culture. On the other hand, he maintains that people will associate not only with members of their own groups but also with members of other groups. This theory applies to the research because organizations consist of different groups and classes of people coming together to achieve an objective and also the importance of communication amongst team members who are employees cannot be overemphasized as individual interest differs.

\section{Empirical Review of Studies on Age and Gender Workforce Diversity}

Adler (2015) study the relationship between diverse recruitment policies and employee performance. He discovered that diversity can enhance organizational performance if there is recruiting from a wider range of cultural and work experience which gives the firm a competitive advantage and enhances profitability. Adler (2015) in his study found that cultural diversity, educational, individual personalities and professional background can influence the range and depth of information use in the workforce. In another empirical study by the Runnymede Trust (2000) titled "Survey on racial equality", it observed that managers explained their equal opportunities policy differently from employee views about what happened in practice. Creegan et al. (2003) examined the role of a culture equality action plan and discovered that there is higher competitiveness when different culturally diverse groups work together. Gupta (2013) in his study propel that high levels of cultural diversity enhance better organizational performance and competitive advantage. He further elaborated that a well-managed cultural composition of employees at the workforce may lead to positive organizational outcomes and greater profitability. Gupta (2013) in his findings reported that work experience diversity is associated with efficient resources that can provide a firm with a sustained competitive advantage. These resources include human capabilities, traits, innovation and improved problem-solving capabilities. Moreover, in the case of routine tasks, there are no substantial gains from age heterogeneity that could offset the increasing costs resulting from greater age heterogeneity. Harrisson, Price and Bell (1998) in the study found that different cultural groups provide different values for companies and these values can complement each other which improves companies' performance and efficiency (Ricardo, 2016; Childs, 2016). 


\section{Gaps in Literature}

The resource-based view of the firm suggests that there is a positive relationship between diversity \& performance (Cox, 2001; Price, 1977; Ricardo, 2016; Carrel, 2016), whereas social identity theory of Tajfel and Turner, (1986) found a negative relationship between diversity and performance. Decades of researches on employee diversity and organizational performance have shown that only very few researches on employee diversity and its effect on organizational performance have been conducted in Africa precisely Nigeria. Some that exist, focused more on diversity effect on employee performance or productivity, not so much have been done to inspect the effect of employees diversity on organizational performance. Empirical research has found inconsistent results suggesting that diversity can be either good or bad for business.

\section{Research Method}

This research study adopted the Survey Research Method to explore Employee diversity and its influence on the employment coefficient of Nigeria's multinational Food companies. The survey method involved the use of the structured questionnaire, which was designed to obtain data from respondents on their perception of Employee diversity and its influence on the employment coefficient of Nigeria's multinational corporations. This research study adopted the descriptive research design. The instrument used for gathering data was designed and is subjected to a validity and reliability test (Cresswell, 2009). The target population for this study is the employees of multinational corporations in Nigeria, which helped to determine the sample frame and sample size. The procedure for data collection was done with the aid of a research instrument, which was designed from existing instruments. When the data is collected and collated, it was analyzed using frequencies, inter-item correlation, correlation and regression tools with the aid of Statistical Package for Social Sciences (SPSS). The study population cuts across all levels of employees in the multinational Food companies. The study selected five multinational corporations in the Southwest that are homogenous and are listed on the Nigerian Stock Exchange. The hierarchical structure of the study population is made up of three tiers, which include Top, Middle and Low-level employees. The characteristic of the study population was mixed at every level of the multinationals irrespective of gender, age, marital status, number of dependents, highest educational qualification, job status and years worked in the corporation.

Table 1. List of the selected multinational firms in the South West, Nigeria

\begin{tabular}{|l|l|l|c|c|c|c|}
\hline S/N & \multicolumn{1}{|c|}{ COMPANY } & LOCATION & CEO & $\begin{array}{l}\text { EXECUTIVE } \\
\text { DIRECTORS }\end{array}$ & OFFICERS & $\begin{array}{c}\text { NO. OF SAMPLES FOR } \\
\text { EACH COMPANY }\end{array}$ \\
\hline 1 & PZ Cussons Plc & South West & 1 & 12 & 4,961 & 75 \\
\hline 2 & Unilever Plc. & South West & 1 & 8 & 944 & 75 \\
\hline 3 & Cadbury Plc & South West & 1 & 6 & 727 & 75 \\
\hline 4 & Nestle Plc & South West & 1 & 9 & 2,325 & 75 \\
\hline 5 & GlaxoSmithKline Plc & South West & 1 & 7 & 419 & $\mathbf{3 7 5}$ \\
\hline & TOTAL & $\mathbf{5}$ & $\mathbf{4 5}$ & $\mathbf{9 , 3 7 6}$ & \\
\hline
\end{tabular}

Source: Researchers Compilation, 2019

Table 1. shows the five (5) selected multinational Food firms in South-West Nigeria, with their number of employees, As shown in their annual reports as at 2016, the total number of the employees were 9,367, which was used as the total population for the study. The companies include. PZ Cussons, Unilever Plc, Cadbury, Nestle and GlaxoSmithKline Plc. The basis for considering the multinational Food firms in the South-West is based on the fact that most multinational Food firms have their headquarters and Plants located in Lagos and Ogun State.

1. They are quoted on the floor of the Nigerian stock exchange.

2. Have existed for a minimum of 10 years.

3. Posted an annual balance sheet of two billion and above.

4. Involved in nationwide physical distribution of products.

5. They are present in all the six geographical zones of Nigeria.

6. The organizations are similar in technology they employ.

7. The organizations are autonomous; self-contained entities.

The sample size for this study was determined using the software called MaCorr Sample Size Calculator. The calculator consisted of fields that allowed input of population size and level of significance. The sample size was determined with 9,367 employees using $95 \%$ as the confidence level, which meant we were $95 \%$ certain 
that the sample is real and repeatable. Below is a pictorial representation of the MaCorr Sample Size Calculator in operation.

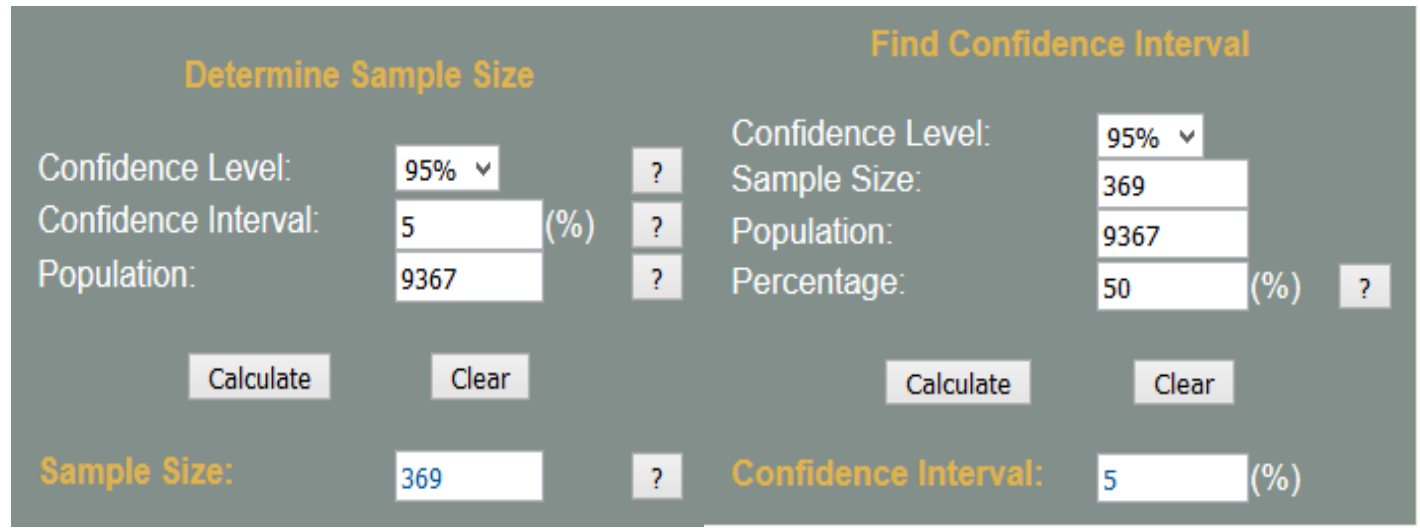

Figure 1. Step 1

Figure 2. Step 2

Source: www.macorr.com (Maccor Sample Size Calculator)

From Figures 1-2, 5\% or 0.05 confidence level was selected with 5 entered at the confidence interval space, while the population size $(9,367)$ was entered in the population cell. When the "calculate" button was clicked, the sample size figure was generated as shown in Figure 2. The sample size for this is 369 and represents the number of respondents across the multinational corporations to which copies of the questionnaire will be administered. The use of the software was justified by professionals in various industries as stated on the website (http://www.macorr.com) from where the software was downloaded. The 60 professionals had made use of the software and it yielded their results. A comparison of results from the MaCorr Sample Size Calculator with those from conventional formulas, such as Yard and Yamane's formulas, showed no marked difference. The sample size of 369 employees will be spread among the 5 selected multinationals companies in Nigeria and respondents were selected randomly to give all the companies equal opportunities of being studied. The sample size for this study was determined using Yamane's sample size formula. Giving the population of 9,367 , a $95 \%$ confidence level and $\mathrm{P}=5 \%$ the equation is thus presented as:

$n=\mathrm{N} 1+\mathrm{N}(e) 2$

Where $\mathrm{n}$ is the sample size, $\mathrm{N}$ is the population size, and "e" is the level of precision. The computed sample size, therefore, using Yamane's formula was:

If $\mathrm{n}=$ Sample Size

$\mathrm{N}=9,367$ Employees

$e=5 \%$ or 0.05

$\mathrm{CL}=95 \%$

Therefore, $n=9,367 * 1+9,367(0.05) 2$

$\mathrm{n}=374.70$

$\mathrm{n}=\sim 380$ Employees

Approximately 380 employees were calculated as the sample size using Yamane's sample size formula. This meant that averagely 70 copies of the questionnaire were administered in each of the multinational corporations. A simple random sampling method was used in the selection of 369 multinational corporations' employees in Nigeria. Simple random sampling was adopted because of the homogeneous characteristics of the study population, that is, non-managerial employees (Top, middle and lower-level employees) of 5 multinational firms in Nigeria. Also, each element of the population had an equal chance of being selected and represented. The selection of employees from the multinational firm was based on the adoption of the stratified random sampling technique, which is attributed to (Maguire, 2005). For this research project, the face validity approach was adopted whereby three Faculty Professors examined the questionnaire, make relevant corrections which were implemented based on the belief that the instrument is appropriate. Towards this end, the test re-test reliability approach was adopted for the research. Reliability was ensured by the test re-test. Content analysis was used to identify similar patterns in respondents' responses to the open-ended questions. Statistical analysis, on the other hand, enabled the researcher to calculate correlation, partial correlation, 
multiple regression, hierarchical multiple regression and one-way analysis of Variance (ANOVA), which was used in testing the two stated hypotheses.

\section{Data Presentation, Analysis, Interpretation and Discussion of Findings}

\section{Data Presentation}

The research questionnaire was administered to three hundred and seventy-five (375) employees which is the sample size representing the chosen study population of the 5 selected multinational food industry in Southwest Nigeria. Of this lot, three hundred (300) questionnaires representing $80 \%$ were returned, and seventy-five (75) questionnaires representing $20 \%$ were not returned. The table below shows the details at a glance.

Table 2. Analysis of Response Rate

\begin{tabular}{|l|c|c|}
\hline \multicolumn{1}{|c|}{ Questionnaire } & Respondents & Percentage (\%) \\
\hline Returned & 300 & 80 \\
\hline Not Returned & 75 & 20 \\
\hline Total Distributed & $\mathbf{3 7 5}$ & $\mathbf{1 0 0}$ \\
\hline
\end{tabular}

Source: Author's Fieldwork Computation, 2019

Table 3. Frequency Distribution of the Respondents' Demographic Characteristics

\begin{tabular}{|c|c|c|c|c|}
\hline CHARACTERISTICS & CATEGORY & FREQUENCY & PERCENTAGE & CUMULATIVE PERCENT \\
\hline \multirow{2}{*}{ Sex } & Male & 189 & 63 & 63 \\
\hline & Female & 111 & 37 & 100 \\
\hline \multirow{3}{*}{ Marital Status } & Single & 84 & 28 & 28 \\
\hline & Married & 146 & 48.7 & 76.7 \\
\hline & Others & 70 & 23.3 & 100 \\
\hline \multirow{4}{*}{ Work Experience } & $1-5 y r s$ & 136 & 45.3 & 45.3 \\
\hline & $6-10 y r s$ & 99 & 33 & 78.3 \\
\hline & $11-15 y r s$ & 45 & 15 & 93.3 \\
\hline & Over 15yrs & 20 & 6.7 & 100 \\
\hline \multirow{3}{*}{ Management category } & Lower level & 71 & 23.7 & 23.7 \\
\hline & Middle level & 180 & 60 & 83.7 \\
\hline & Top level & 49 & 16.3 & 100 \\
\hline \multirow{4}{*}{ Educational Qualification } & SSCE & 57 & 19 & 19 \\
\hline & HND/BSc & 196 & 65.3 & 84.3 \\
\hline & MSc/MBA & 36 & 12 & 96.3 \\
\hline & Others & 11 & 3.6 & 100 \\
\hline \multirow{4}{*}{ Age } & $21-30$ & 146 & 48.7 & 48.7 \\
\hline & $31-40$ & 95 & 31.7 & 80.3 \\
\hline & $41-50$ & 26 & 8.6 & 89 \\
\hline & Above 50 & 33 & 11 & 100 \\
\hline \multirow{6}{*}{ Multinational Organization } & Nestle PLC & 50 & 16.7 & 16.7 \\
\hline & Stallion group & 42 & 14 & 30.7 \\
\hline & Cadbury PLC & 37 & 12.3 & 43 \\
\hline & Unilever PLC & 75 & 25 & 68 \\
\hline & PZ Cussons PLC & 57 & 19 & 87 \\
\hline & Others & 39 & 13 & 100 \\
\hline
\end{tabular}

Source: Author's Fieldwork Computation, 2019

\section{Test for Hypothesis One}

$\mathrm{Ho}_{1}$ : Cultural diversity and Work experience do not significantly affect Market share.

Standard multiple regression was used to explore the effects of Cultural diversity and Work experience on Market share. Preliminary analyses were performed to ensure no violation of the assumptions of normality, Multicollinearity, homoscedasticity and linearity. The result of regression as contained in Table 4. ANOVA shows that the F-test was 1.072 , significant at 5 percent $[p<.370]$. This showed that the model was well specified.

Table 4. ANOVA

\begin{tabular}{|l|l|c|c|c|c|c|}
\hline \multicolumn{2}{|l|}{ Model } & Sum of Squares & Df & Mean Square & F & Sig. \\
\hline \multirow{4}{*}{1} & Regression & 1.392 & 4 & .348 & 1.072 & $.370^{\mathrm{b}}$ \\
\cline { 2 - 7 } & Residual & 95.736 & 295 & .325 & & \\
\cline { 2 - 7 } & Total & 97.128 & 299 & & & \\
\hline
\end{tabular}

Source: Author's Fieldwork Computation, 2019 
Also, the result of regression as contained in Model Summary, shows that the R Square gave a value of 14 percent. This means that the model (Cultural diversity and Work experience) explained about 14 percent of the variance in perceived Market share.

Table 5. Model Summary

\begin{tabular}{|c|c|c|c|c|}
\hline Model & R & R Square & Adjusted R Square & Std. Error of the Estimate \\
\hline 1 & $.120^{\mathrm{a}}$ & .014 & .001 & .56967 \\
\hline \multicolumn{2}{|l|}{ a. Predictors: (Constant), Age diversity, Cultural Diversity, Gender diversity, Work experience } \\
\hline
\end{tabular}

Source: Author's Fieldwork Computation, 2019

Specifically, the result of regression as contained in Table 6. Regression Coefficients tests the third hypothesis of this study. From the output below, there was a positive relationship between perceived cultural diversity and perceived customer loyalty such that a unit increase in cultural diversity scores caused about .007-unit increase in perceived Market share scores which was statistically not significant at 5 percent with the aid of the p-value (0.937). Based on the result, the null hypothesis is accepted; thus, cultural diversity did not affect Market share. Also, there was a positive relationship between perceived work experience and perceived Market share such that a unit rise in perceived work experience scores induced about .134-unit increase in perceived Market share scores which was statistically not significant at 5 percent going by the p-value (0.116). Based on the result, the null hypothesis is accepted; thus, the Market share is not affected by work experience.

Table 6. Regression Coefficients

\begin{tabular}{|c|c|c|c|c|c|c|}
\hline \multirow{2}{*}{\multicolumn{2}{|c|}{ Model }} & \multicolumn{2}{|c|}{ Unstandardized Coefficients } & \multirow{3}{*}{$\begin{array}{c}\text { Standardized Coefficients } \\
\text { Beta } \\
\end{array}$} & \multirow{3}{*}{$\begin{array}{c}\mathbf{T} \\
7.872 \\
\end{array}$} & \multirow{3}{*}{$\begin{array}{l}\text { Sig. } \\
.000\end{array}$} \\
\hline & & \multirow{2}{*}{$\begin{array}{c}\mathbf{B} \\
3.478 \\
\end{array}$} & \multirow{2}{*}{$\begin{array}{c}\text { Std. Error } \\
.442\end{array}$} & & & \\
\hline 1 & (Constant) & & & & & \\
\hline & Cultural Diversity & .007 & .090 & .005 & .079 & .937 \\
\hline & Work experience & .134 & .085 & .112 & 1.576 & .116 \\
\hline & Gender diversity & -.067 & .094 & -.047 & -.711 & .477 \\
\hline & Age diversity & .035 & .086 & .029 & .411 & .681 \\
\hline
\end{tabular}

Source: Author's Fieldwork Computation, 2019

\section{Test for Hypothesis Two}

Ho3: Work experience does not significantly affect Employee Turnover.

Standard multiple regression was used to explore the effects of Work experience on Employee Turnover. Preliminary analyses were performed to ensure no violation of the assumptions of normality, Multicollinearity, homoscedasticity and linearity. The result of regression as contained in Table 7. ANOVA shows that the Ftest was 0.974 , significant at 5 percent $[p<.422]$. This showed that the model was well specified.

Table 7. ANOVA

\begin{tabular}{|l|l|c|c|c|c|c|}
\hline \multicolumn{2}{|c|}{ Model } & Sum of Squares & df & Mean Square & F & Sig. \\
\hline \multirow{4}{*}{1} & Regression & .959 & 4 & .240 & .974 & $.422^{\text {b }}$ \\
\cline { 2 - 7 } & Residual & 72.664 & 295 & .246 & & \\
\cline { 2 - 7 } & Total & 73.623 & 299 & & & \\
\hline
\end{tabular}

Source: Author's Fieldwork Computation, 2019

Also, the result of regression as contained in Table 8. Model Summary shows that the R Square gave a value of 13 percent. This means that the model (Cultural diversity and Work experience) explained about 13 percent of the variance in perceived market share.

Table 8. Model Summary

\begin{tabular}{|l|c|c|c|c|}
\hline Model & R & R Square & Adjusted R Square & Std. Error of the Estimate \\
\hline 1 & $.114 \mathrm{a}$ & .013 & .000 & .49631 \\
\hline \multicolumn{2}{|l}{ a. Predictors: (Constant), Cultural Diversity, Gender diversity, Age diversity, Work experience } \\
\hline
\end{tabular}

Source: Author's Fieldwork Computation, 2019

Specifically, the result of regression as contained in Table 9. Regression Coefficients tests the fourth hypothesis of this study. From the output below, there was a positive relationship between perceived work experience and perceived employee turnover such that a unit increase in work experience scores caused about .021-unit increase in perceived employee turnover scores which was statistically not significant at 5 percent with the aid of the p-value (0.776). Based on the result, the null hypothesis is accepted; thus, work experience did not affect 
employee turnover. Lastly, there was a positive relationship between perceived cultural diversity and perceived employee turnover such that a unit increase in cultural diversity scores caused about .026-unit increase in perceived employee turnover scores which was statistically not significant at 5 percent with the aid of the pvalue (0.744). Based on the result, the null hypothesis is accepted; thus, cultural diversity did not affect employee turnover.

Table 9. Regression Coefficients

\begin{tabular}{|c|c|c|c|c|c|c|}
\hline \multirow{2}{*}{\multicolumn{2}{|c|}{ Model }} & \multicolumn{2}{|c|}{ Unstandardized Coefficients } & \multirow{2}{*}{$\begin{array}{c}\text { Standardized Coefficients } \\
\text { Beta }\end{array}$} & \multirow{2}{*}{$\mathbf{T}$} & \multirow{2}{*}{ Sig. } \\
\hline & & $\mathbf{B}$ & Std. Error & & & \\
\hline \multirow[t]{5}{*}{1} & (Constant) & 3.199 & .385 & & 8.311 & .000 \\
\hline & Work experience & .021 & .074 & .020 & .284 & .776 \\
\hline & Gender diversity & .012 & .082 & .010 & .144 & .885 \\
\hline & Age diversity & .091 & .075 & .086 & 1.218 & .224 \\
\hline & Cultural Diversity & .026 & .079 & .022 & .327 & .744 \\
\hline
\end{tabular}

Source: Author's Fieldwork Computation, 2019

\section{Discussion of Findings}

The findings of the study revealed a positive relationship between cultural diversity and Market share such that cultural diversity does not affect employees' performance in the organization. Cultural diversity can be defined as the ethnic, gender, racial and socio-economic variety in a situation, institution or group; the coexistence of different ethnic, gender, racial, and soci-economic groups within a society. In conclusion, modern organizations would highly be impressed with the findings that the culture diversity of customers does not affect customer's Market share in their organization. The outcome of this study resonates with the views of Afolabi and Aina (2016) which explains that work experience was a better predictor of performance than age. Findings also showed that experience exhibit nonlinear relationships with performance. Experienced workers generally are viewed as dependable, loyal, and dedicated. They are also viewed as having a strong work ethic, solid performance record, due to possessing years of working related experience. Work experience can also have a positive effect on one's value system, problem-solving capabilities, emotional intelligence, leading to improved individual productivity and overall organizational performance. Based on this finding, work experience does not affect employee turnover in the organization that is no matter how much the experience is, it has no effect on employee turnover. In conclusion, this research finding is in line with previous researches of experts that have discovered that work experience does not affect employee turnover.

\section{Implication of the Findings in Practice for MNCs and TNCs}

The question of how employee diversity affects organizational performance is still being debated till date. An organization, therefore, has the final decision on which action to take as regards diversity. For example, some multinational organizations in Nigeria believe in all forms of diversity and all the forms can be instrumental in achieving organizational performance. The result of this study has shown the importance of employee diversity on organizational performance using the multinational food industry and examining how it relates to a human resource professional. Human resource professionals should ensure the public is aware of the diversity existent in the organization in other to boost employee's morale and enhance their performance thereby increasing customer satisfaction and Sales patronage. Human Resource Professionals of MNCs/ TNCs are compelled to create a diverse workforce from time to time and highlights the result of employee diversity on the performance of the organization to the top management.

\section{Conclusion}

The research concludes that there exists a relationship between employee diversity and organizational performance. The study concludes that there is a positive relationship between the variables of employee diversity which include work experience diversity and cultural diversity. The findings of this study have shown that there exists a positive relationship between work experience diversity and employee turnover. It was revealed that work experience diversity is affected by employee turnover. Moreover, the findings have indicated that cultural diversity affected the degree at which market share is achieved and the effectiveness of performance in the organization. This research finding is tangential to past findings by Afolabi and Aina (2004) and Gupta (2013) that have discovered that work experience diversity has the tendencies to affect employee turnover. The findings of the study have concluded that there is a positive relationship between cultural diversity and market share. The findings are in consonance with the previous findings of Dimotosa (2012) and Gelner \& Veen (2013) that cultural diversity has the likelihood to affect market share. The research on work experience diversity is much less developed than that of cultural diversity, suggesting the need for new 
paradigms and new approaches to studying work experience diversity in the work setting. The findings and conclusions of this research are possible to be implemented in all multinational food industries in Nigeria based on the fact that Ninety percent of multinational Food firms in Nigeria have their headquarters and Plants located in Southwest Nigeria.

\section{Suggestions for Further Research}

1. Future research should focus on other firms within the other sector and not limited to food and beverage and conglomerate sectors of the Nigerian economy. The impact of employee diversity on organizational performance in other industries and sectors apart from the ones sampled in this research, for example, manufacturing industry and the small and medium enterprise sector.

2. It is also suggested that the research horizon of other researchers could center on harnessing the views of other stakeholders such as; the government, customers of these firms, suppliers amongst other key stakeholders.

\section{References}

1. Adler, N. J. (2015). Cultural Synergy: Managing the Impact of Cultural Diversity. London: Sage Publications. Volume 5(11), November 2016. Available at: https://www.researchgate.net/publication/310455811.

2. Afolabi, F. \& Aina, O. (2014). Gender differentials in subjective well-being among religious elderly Yoruba people in Southwest Nigeria. Ageing International, 39(2), 180-193. doi: 10.1007/s12126-014-9197-8.

3. Afolabi, O.A. and Omole, E.O. (2011). Personality Type and Workforce Diversity as Predictors of Ethical Behavior and Job Satisfaction Among Nigerian Policemen. Current Research Journal of Social Sciences. 3. 381-388. Available at: https://pdfs.semanticscholar.org/556e/d86af8aabab21971d6235ba3b96.

4. Ajala, A.O.A and Alonge, K.S. (2013). Gender Issues in basic education and national development in Nigeria. Journal of Emerging Trends in Educational Research and Policy Studies (JETERAPS), 4(4), 644649. Available at:

http://jeteraps.scholarlinkresearch.com/articles/Gender\%20Issues\%20in\%20Basic\%20Education.pdf.

5. Akinnusi, D. M., Sonubi, O., Oyewunmi, A. E. (2017). Fostering Effective Workforce Diversity Management. International Review of Management and Marketing in Nigerian Organizations: The Challenge of Human Resource Management, 7(2), 108-116. Available at: https://EconPapers.repec.org/RePEc:eco:journ3:2017-02-17.

6. Allen, D., Bryant, P., Vardaman, M. (2010). Retaining Talent: Replacing Misconceptions with EvidenceBased Strategies. Academy of Management Perspectives, 48-64. /doi.org/10.5465/amp.24.2.48.

7. Al-Lamki, S. M. (2014). Orientation: The essential Journal of Management. Ingredient in cross-cultural Management, 19, 568. Available at: http://www.irjmst.com/article_pdf?id=6974.pdf.

8. Atta-Asamoah, A. (2012). Overview of the Nature and Management of Diversity in Africa. Prepared for the Office of the Special Adviser on Africa (OSAA), Institute for Security Studies, Pretoria, South Africa. https://doi.org/10.5897/AJBM2017.8316.

9. Armstrong, M., (2012). Armstrongs Handbook of Human Resource Management Practice. 12th ed. London: Kogan Page. Available at: https://www.koganpage.com.

10.Blau, P. M. (1977). Inequality and heterogeneity. New York: Free Press. Available at: http://www.ncjrs.

11.Borman, W. C., Penner, L. A. (2001). Citizenship performance: Its nature, antecedents, and motives. In Personality psychology in the workplace, ed. B. W. Roberts and R. Hogan, 45-61. Washington, dc: American Psychological Association. https://doi.org/10.1037/10434-002.

12.Carrel, M. R., Mann, E. E., and Sigler, T. H. (2006). Defining workforce diversity programs and practices in organizations: a longitudinal study. Labor Law Journal. Spring, 57(1), 5-12. Retrieved from www.emeraldinsight.com.

13.Childs, J. (2016). Managing workforce diversity at IBM: A global HR topic that has arrived. Human Resource Management, 44(1), 73-77. DOI: http://dx.doi.org/10.1002/hrm.20042.

14.CIPD (2014). Employee Turnover and Retention. Turnover-retention.aspx. Available at: https://www.cipd.co.uk/knowledge/strategy/resourcing/turnover-retention-factsheet.

15.Cox, T.H. (2001). Cultural diversity in organisations: theory, research and practice.SanFrancisco, CA: Berrett-Koehler. Human Resource Development Review, 10(1), 7-30. doi:10.100711618-007-0003-1.

16.Creswell, J. W. (2009). Educational research Planning, conducting and evaluating quantitative and qualitative research. ( $2^{\text {nd }}$ Ed) Upper Saddle River, N.J: Pearson Education. Available at: https://trove.nla.gov.au/work/10569727. 
17.Danladi, S.S. (2013). Language policy: Nigeria And the role of English language in the 21st Century. European Scientific Journal, 9(17). https://books.google.com.ng/books?id=G.

18.Daudi, P., Nguyen, K. (2010). The Ethical Challenge of Multinational Corporations in Inadequate Institutions: The Case of Shell in Nigeria (November 30, 2010). Available at SSRN: http://ssrn.com/abstract=2039786 or http://dx.doi.org/10.2139/ssrn.2039786.

19.Ditomasso, N. (2015). Understanding the Effects of Workforce Diversity on Employment Outcomes: A Multidisciplinary and Comprehensive Framework. Paper presented at the annual meeting of the American Sociological Association, Hilton SanFrancisco and Renaissance. San Francisco. Emerald Group Publishing Limited. Retrieved from http://www.allacademic.com.

20.Duncan, C. (2013). Assessing Ant-Ageism Routes to Older Worker Re-Engagement. Work Employment And Society, 17(1), 101-120. Available at:

http://www.ijhssnet.com/journals/Vol_6_No_6_June_2016/8.pdf.

21.Erasmus, L. J. (2016). The Management of Workforce Diversity and the Implications for Leadership at Financial Asset Services. Business Management, University of Johannesburg. PhD Thesis. Available at: file:///C:/Users/HP/Downloads/PDF\%20Document.pdf.

22.Friday, E., Friday, S.S. (2013). Managing diversity using a strategic planned change Approach. Journal of Management Development, 22, 863-880. doi: 10.1108/02621710310505467.

23.Gelner, B., Veen, S. (2013). Positive Effects of Aging And Age Diversity In Innovative Companies: Large Scale Empirical Evidence on Company Productivity. Human Resource Management Journal, 3(3), 279-295. https://doi.org/10.1111/1748-8583.12011.

24.Greenberg, J. (2012). Diversity in the Workplace: Benefits, Challenges and Solutions. Retrieved on February 27, 2014 from http://diversity.sdce.edu/content/diversity-workplace-benefits-challenges-andsolutions.

25.Griffeth, W., Hom, W. (2001). Retaining valued employees. Thousand Oaks, CA: Sage. Available at: https://books.google.com.ng.

26.Gupta R. (2013). Workforce Diversity and Organizational Performance. International Journal of Business Management Invention, 2(61), 36-44. Available at: http://www.ijhssnet.com/journals/Vol_6_No_6_June_2016/8.pdf.

27.Harrison, D. A., Price, K. H. \& Bell, M. P. (1998). Beyond relational demography: Time and the effects of surface- and deep-level diversity on work group cohesion. Academy of Management Journal, 41(1), 96-107. DOI: $10.2307 / 256901$ https://www.jstor.org/stable/256901.

28.Hassan, O. M. (2013). The Inevitability of Multinational Corporations towards Achieving Sustainable Development in Developing Economies: A Case Study of the Nigerian Economy. American Journal of Business and Management, 2(3), 256-265. DOI: 10.11634/216796061302415.

29.Kochan, T., Bezrukova, K., Ely, R., Jackson, S., Joshi, A., Jehn, K., Leonard, J., Levine, \& Thomas (2012). The effects of diversity on business performance: Report of the diversity research network. Journal of Human Resources Management, 42(1), 3-21. https://doi.org/10.1002/hrm.10061.

30.Konrad, Alison M. (2003). Managing Workforce Diversity in Competitive Environment. Group \& Organization Management, 28(1). https://doi.org/10.1177/1059601102250013.

31.Long, S., Perumal, P. and Ajagbe, M., (2012). The Impact of Human Resource Management Practices on Employees Turnover Intention: A Conceptual Model. Interdisciplinary Journal of Contemporary Research in Business, 4(2), 629-641. Available at: https://journal-archieves19.webs.com/629-641.pdf.

32.Maurer, T. J., Wrenn, K. A., Pierce, H. R., Tross, S. A., Collins, W. C. (2013). Beliefs about 'improvability' of career-relevant skills: Relevanceto job/task analysis, competency modelling, and learning. https://doi.org/10.1002/job.182.

33.Maxwell, G. A., Blair, S., McDougall, M. (2015). Edging towards managing diversity in practice. Employee Relations, 23(5), 468-482. https://pdfs.semanticscholar.org.

34.Meyer, J. and Sternthal, B. (1991). Gender Differences in the Use of Message Cues and Judgments. Journal of Marketing Research, 28 (February), 84-96. https://doi.org/10.1177/002224379102800107.

35.Ndubisi, N. O. (2006). Effect of gender on customer loyalty: a relationship marketing approach. Marketing Intelligence and Planning, 24(1), 48-61. https://doi.org/10.1108/02634500610641552.

36.Oliver, Richard L. (1999). Whence Consumer Loyalty? Journal of Marketing, 63 (Special Issue), 33-44. https://doi.org/10.1177/00222429990634s105.

37.Ogunyinka, E.K. (2013). Higher education funding and cost sharing: case study of universities in Nigeria. Academic Research International, 4(5). Available at: https://www.scribd.com/document/. 
38.Ojo, G. U. (2012). Economic diversification and second-tier political conflict:assessing bitumen political ecologies in southwest Nigeria. Singapore Journal of Tropical Geography, 33(1), 49-62. doi:10.1111/j.1467-9493.2012.00447.x.

39.Okpanachi, E. (2012). Ethno-religious Identity and Conflict in Northern Nigeria. Available at: http://www.cetri.be/spip.php?article2470\&lang=fr (Accessed 6 October 2014).

40.Otike W., Messah B., \& Mwaleka K. (2010). Effects of Workforce Diversity on Organizational Effectiveness: A Case Study On Kenya Commercial Bank Ltd. Journal Of Business And Management. Available at: www.iiste.org.

41.Ozbilgin M., Tatli A. (2016). Global diversity management: An evidence-based Approach. London, England: Palgrave. Available at: https://www.academia.edu/165112.

42.Pan, Y., \& Zinkhan G.M. (2006). Determinants of retail patronage: A meta-analytical prospective. Journal of Retailing, 83(1), 229-243. Available at: https://ecommons.udayton.edu/mgt_fac_pub/47/.

43.Porter, M. (1987). From competitive advantage to corporate strategy. Harvard Business Review, May June, 43-59. Available at: https://maaw.info/ArticleSummaries/ArtSumPorter1987.htm.

44.Price, J. L. (1977). The Study of Turnover. Ames, Iowa: Iowa State University Press (Book review). Work and Occupations, 5(4). https://doi.org/10.1177/073088847800500406.

45.Ricardo, R. (2016). Corporate Performance Management: How to Build A Better Organization Through Measurement Driven Strategies Alignment. Butterworth Heinemann. Available at: https://trove.nla.gov.au/work/32533654.

46.Richard, O. C. (2014). Racial diversity, business strategy and firm performance: A resource based view. Academy of Management Journal, 43, 164-177. https://doi.org/10.5465/1556374.

47.Roberson, M.Q. \& Park, H. J. (2007). Examining The Link Between Diversity And Firm Performance: The Effects of Diversity Reputation and Leader Racial Diversity. Group \& Organizational Management, 32(5). DOI: $10.1177 / 1059601106291124$.

48.Singh, Ramadhar, and Soo Yan Ho (2000). Attitudes and Attraction: A New Test of the Attraction, Repulsion and Similarity-Dissimilarity Asymmetry Hypotheses. British Journal of Social Psychology, 39(2), 197-211. https://doi.org/10.1348/014466600164426.

49.Sungjoo and Hal Rainey (2010). Managing Diversity in U.S. Federal Agencies: Effects of Diversity and Diversity Management on Employee Perceptions of Organizational Performance. Public Administration Review, 70(1), 109-121. Available at: 227700249_Managing_Diversity_in_US_Federal_Agencies_Effects_of_Diversity_and_Diversity_Manag ement_on_Employee_Perceptions_of_Organizational_Performance.

50.Tajfel, H. (1986). Differentiation between social groups: studies in the social psychology of intergroup relations. Academic Press, New York. DOI: 10.1111/j.1540-6210.2009.02115.x.

51.Taylor, S. (2002). The Employee Retention Handbook. London: CIPD. Available at: https://www.pearson.com/uk.

52.Thomas, D. A. \& Eli, R. J. (2014). Making differences matter: A new paradigm for managing diversity. Harvard Business Review. September-October, 77-90. Available at: https://hbr.org/1996/09/making.

53.Torrington, D., Hall, L., and Taylor, S. (2015). Human Resource Management. Sixth Edition. London: Pearson education Ltd. Available at: https://www.amazon.co.uk.

54.Zheng, C., Hyland, P., \& Soosay, C. (2013). Training practices of multinational companies in Asia. Journal of European Industrial Training, 31(6), 472-494. DOI: 10.1108/03090590710772659. 